\title{
KAJIAN KONSISTENSI SIKAP DAN PERBUATAN BERBAHASA INDONESIA BIDANG KEILMUAN
}

\author{
Marsudi, Siti Zahrok \\ UPT PMK Sosial Humaniora ITS, Surabaya, 60111. \\ marsudi@mku.its.ac.id
}

Diterima: 09 Agustus 2017

Direview: 04 Oktober 2017

Diterbitkan: 30 November 2017

Hak Cipta (C) 2017 oleh Penulis (dkk) dan Jurnal Sosial Humaniora (JSH)

*This work is licensed under the Creative

Commons Attribution International License (CC

BY 4.0).

http://creativecommons.org/licenses/by/4.0/ Open Access

\section{Subject Areas: Socio-Linguistics}

\begin{abstract}
Attitude can be defined as permanent sense, thought, and preference on specific aspect of life. In fact, language attitude of speakers of Bahasa Indonesia is interesting to be questioned. In relation to this, the aim of this research is to describe consistency in terms of language attitude and language performance among Bahasa Indonesia users. Positive thought and sense toward Bahasa Indonesia should be completely or at least partly actualized on the use of standard language when it is implemented in academic setting. In this article used the approach of qualitative methods, namely the object of study in this article has a natural character. This approach is expected to find the phenomena and social problems that occur in the object of study. Cases found in the use of Bahasa Indonesia tend to oppose the essence of language attitude Inconsistency among bahasa Indonesia attitude lies on the level of spelling, diction, and sentence structures The causes of this inconsistency rest on the disparage and ignorance of Bahasa Indonesia language principles The use of Bahasa Indonesia ignoring language principles particularly on academic setting is viewed as unimportant and unurgent matter. Therefore, negative attitude emerges as a result of ignored language principles
\end{abstract}

Keywords: attitude consistency; language attitude; academic language

\section{Pendahuluan}

Bahasa Indonesia merupakan bahasa nasional dan bahasa negara, maka sudah selayaknya mahasiswa sebagai calon pemimpin bangsa menyadari dan memahami keberadaan norma dan kaidah bahasa Indonesia, terutama bahasa Indonesia bidang keilmuan. Sangat tidak elok jika dalam berkomunikasi ilmiah, mahasiswa sebagai calon pemimpin bangsa menggunakan bahasa Indonesia dengan tidak baik dan benar sehingga melanggar kaidah bahasa Indonesia yang telah ditetapkan. Jika diperhatikan dengan seksama, alat komunikasi yang paling intensif digunakan adalah bahasa, baik komunikasi lisan maupun komunikasi tulis. Namun sayang begitu intensifnya aktivitas kita dengan bahasa, terutama bahasa Indonesia, sehingga banyak yang menganggap tidak perlu mendalami dan mempelajari bahasa Indonesia secara lebih jauh. Akibatnya, sebagai pemakai bahasa, orang Indonesia tidak terampil menggunakan bahasa. Suatu kelemahan yang tidak disadari.

Dalam aktivitas sehari-hari, masih sering terjadi percampuran bahasa daerah atau bahasa setempat dalam penggunaan bahasa Indonesia. Sejalan dengan kemajuan jaman, penggunaan bahasa Indonesia dalam aktivitas sehari-hari tidak hanya bercampur dengan bahasa daerah dan bahasa ibu, tetapi juga bercampur dengan bahasa-bahasa asing atau pun 
bahasa remaja yang sering disebut dengan bahasa gaul. Apabila peristiwa ini terus berlangsung, akibat yang terjadi adalah kekacauan dalam berbahasa, terutama berbahasa Indonesia. Kekacauan berbahasa ini diperparah lagi dengan penggunaan bahasa gaul yang sering digunakan para remaja sehingga saat berada dalam situasi yang mengharuskan berbahasa Indonesia formal atau resmi, muncullah fenomena kerancuan berbahasa Indonesia(Marsudi, Siti Zahrok, 2013).

Perkembangan jaman global menempatkan bahasa Indonesia pada situasi kurang menguntungkan. Pemakaian Bahasa Indonesia sangat terabaikan dan sebagian kecil saja masyarakat memandangnya positif; kebanggaan pemilik bahasa Indonesia dalam menggunakan bahasa Indonesia sangat memprihatinkan sehingga kesetiaan dan kebanggaan bahasa Indonesia makin lama semakin rendah, bahkan sebagian besar masyarakat lebih bangga terhadap bahasa asing, terutama bahasa Inggris daripada bahasa Indonesia. Bahasa Indonesia sangat sulit menghindari serangan globalisasi. Hal ini menunjukkan terjadinya melemahnya rasa bangga terhadap bahasa Indonesia sehingga kesetiaan pemakai bahasa Indonesia semakin rendah (Marsudi, 2015).

Jika memperhatikan penggunaan bahasa Indonesia di bidang keilmuan, terutama pada pertemuan-pertemuan, telah terjadi banyak pelanggaran dalam penggunaan bahasa Indonesia yang dilakukan oleh masyarakat. Pelanggaranpelanggaran ini tidak hanya dilakukan dalam bahasa lisan, tetapi juga dalam bahasa tulis. Ketidaktaatan berbahasa Indonesia ini terjadi dapat berbentuk interferensi, alih kode, campur kode, dan sebagainya. Bahkan, judul-judul karya ilmiah, seperti makalah, artikel, proposal, dan laporan mahasiswa hampir sangat sering dicampuri bahasa asing, terutama bahasa Inggris. Penggunaan bahasa asing, misalnya bahasa Inggris dapat digunakan, tetapi jika dalam bahasa Indonesia belum ditemukan kata atau istilahnya yang tepat. Bukan hal yang tidak mungkin jika bahasa asing digunakan tanpa batas, yakni melanggar peraturan dan perundang-undangan kebahasaan di Indonesia, suatu saat nanti bahasa Indonesia terasa asing di negeri sendiri. Faktanya di lembaga-lembaga pendidikan, terutama lembagalembaga pendidikan tinggi sangat tidak asing menggunakan baahasa asing, terutama bahasa Inggris. Berarti, kesadaran masyarakat pemakai bahasa Indonesia terhadap bahasa Indonesia terjadi pertanda kuat pergeseran sikap, yakni kemungkinan masyarakat lebih bangga dan bergengsi sewaktu berbicara dengan menggunakan bahasa Inggris daripada berbicara menggunakan bahasa Indonesia atau lebih nyaman berbicara dengan menggunakan bahasa yang tidak baik dan tidak benar daripada berbicara dengan menggunakan bahasa yang baik dan benar. Peristiwa pemakaian kebahasaan seperti di atas tidak semata-mata disebabkan oleh perkembangan jaman, tetapi hal itu lebih disebabkan sikap para pemakai dan pemilik bahasa Indonesia yang lebih cenderung bersikap negatif.

\section{Metode dan Teknik Analisis}

Penelitian ini menggunakan pendekatan metode kualitatif, yakni objek kajian pada tulisan ini memiliki karakter yang natural. Pendekatan ini diharapkan dapat menunjukkan gejala-gejala dan permasalahan sosial yang terjadi pada objek kajain. Karakter penelitian kualitatif secara ringkas dan tegas seperti dikemukakan Bogdan dan Biklen (dalam Sunarto, 2001: 135-136) sebagai berikut.

1. Qualitative research has the natural setting as the direct source of data and the researchers is the keyinstrument. 
2. Qualitative research is the descriptive.

3. Qualitative researchers are concerned with process rather than simply outcame or products.

4. Qualitative researchers tend to analize their data inductively.

5. "Meaning" is of essential concern to the qualitative approach.

Pada dasarnya, penelitian kualitatif lebih menekankan pada objek yang bersifat alami. Sifat alami atau natural ini dideskripsikan dalam rangka memahami semua gejala yang diteliti. Di samping itu, penelitian kualitatif lebih mengutamakan suatu proses yang terjadi daripada hasil. Dalam penelitian jenis ini, proses menjadi titik perhatian untuk pemaknaan gejala sosial supaya bersifat pembenaran akal sehat. Tidak dapat dilupakan juga bahwa penelitian kualitatif itu bersifat induktif, yakni gejalagejala faktual dijabarkan terlebih dahulu kemudian dilanjutkan perumusan sehingga menjadi suatu simpulan. Pemikiran bersifat deduktif bukan berarti ditinggalkan sama sekali, tetapi tetap digunakan tertama pada saat akhit proses penelitian. Pada akhirnya, dalam penelitian kualitatif lebih mementingkan makna daripada situasi dan hasil.

Objek tulisan sikap dan perbuatan berbahasa Indonesia ini sebagai sumber kajian langsung sehingga penggambaran objek kajian lebih diutamakan daripada hasil. Oleh sebab itu, penganalisisan objek kajian akan dilakukan secara induktif, yakni dimulai dengan menjelaskan berbagai masalah atau fenomena-fenomena faktual yang dapat bersifat empiris dan juga bersifat khusus. Setelah dilakukan penggambaran atau pendeskripsian dan penganalisisan objek kajian kemudian dilakukan penyimpulan sehingga diperoleh pernyataan atau simpulan yang bermakna. Dengan demikian, analisis pada tulisan ini adalah berusaha menemukan makna hubungan antara sikap dan perbuatan berbahasa Indonesia.

Di dalam tulisan ini, sampel atau informan penelitian berupa sampel yang relatif sedikit namun sesuai dengan tujuan penelitian kualitatif. Mengenai sampel penelitian kualitatif, Nasution (1992 dalam Husada) mengatakan bahwa metode kualitatif menggunakan pemilihan sampel berdasarkan tujuan penelitian dan sampel yang diambil cenderung sedikit. Penelitian kualitatif sering berbentuk studi kasus atau multikasus. Penelitian ini tidak menggunakan istilah seperti populasi, tetapi situasi sosial yang terdiri dari tempat dan pelaku dan aktivitas

(http://www.ilmubahasa.net/2016/12/tekniksampling-penelitian-kualitatif.html. diakses Oktober 2017).

Sehungan dengan tulisan ini, terdapat sampel bertujuan atau sering disebut purposive sampling. Mengingat, sampel bertujuan dalam tulisan ini telah melalui pertimbangan dan penyeleksian secara hatihati sehingga diharapkan terhindar dari kecerobohankecerobohan dalam penentuan sampel. Mengingat, pertimbangan atau intuisi peneliti dapat berperan dan terlibat dalam menentukan sampel penelitian kualitatif. Dalam hal ini, Sugiono (2009:305) menjelaskan bahwa dalam penelitian kualitatif yang menjadi instrumen atau alat penelitian adalah peneliti itu sendiri. Selain pendapat tersebut, Bouma Gary D (1993:119) dalam bukunya yang berjudul "The Research Process" mengemukakan dengan tegas bahwa teknik sampel purposif, seorang peneliti percaya bahwa mereka dapat menggunakan pertimbangan atau intuisinya untuk memilih orang atau kelompok terbaik untuk dipelajari atau dapat memberikan informasi yang yang tepat dan akurat (http://www.ilmubahasa.net/2016/12/teknik- 
$\underline{\text { sampling-penelitian-kualita-tif.html. }}$ diakses

Oktober 2017).

Data dalam tulisan ini diperoleh dengan cara kuesioner dan wawancara, yakni (1) penulis sebagai pengampu bahasa Indonesia dapat berasumsi bahwa para responden mengalami kesenjangan antara pengetahuan dan konasi kebahasaan, yang didasarkan pengamatan, (2) penulis melakukan wawancara secara intensif terhadap para responden tentang tujuan belajar bahasa Indonesia yang pernah dilakukan, dan (3) penulis menyiapkan pertanyaan kemudian ditanyakan kepada responden, yakni bagaimanakah pendapat responden tentang strategi pemberdayaan bahasa Indonesia.

\section{Sikap Bahasa}

Sebelum membahas sikap bahasa, di dalam tulisan ini akan dijabarkan tentang pengertian sikap. Mengenai batasan sikap relatif banyak dikemukakan dan diulas para ahli psikologi. Jika diperhatikan, sikap seseorang sulit atau bahkan tidak akan dapat dipisahkan dengan suatu pendapat, keyakinan, atau kecenderungan seseorang mengenai suatu objek yang disertai dengan perasaan tertentu dan dijadikan dasar dalam bertingkah laku dalam kehidupan sehari-hari terhadap suatu objek. Di dalam Kamus Besar Bahasa Indonesia (1989:838), dijelaskan bahwa sikap adalah perbuatan dan sebagainya yang berdasarkan pada perdirian (pendapat atau keyakinan). Seseorang seringkali mengekspresikan sikapnya dalam bentuk pernyataan pendapat, seperti menyukai atau tidak menyukai pada objek tertentu. Dalam mengekspresikan perasaan, seseorang sering dihubungkan dengan kognisi, yakni keyakinan tentang objek sikap. Dengan kata lain, sikap tersebut mengandung komponen afeksi dan kognisi. Mengingat, seseorang dalam bertingkah laku itu sangat sulit dipisahkan dengan sikap yang dimilikinya. Dengan demikian sikap merupakan kesiapan individu yang mengacu pada berbagai cara tingkah laku sehingga tingkah laku seseorang itu sebagai wujud konsistensi sikap terhadap objek. Berarti, sikap itu akan dimanifestasikan dalam wujud perilaku nyata seseorang dalam berinteraksi ataupun berkomunikasi dengan sesama manusia; sikap itu mengandung afeksi dan kognisi. Oleh sebab itu, seseorang dalam bertingkah laku sulit dipisahkan dengan sikap yang dimilikinya.

Menurut Lambert (dalam Hohental, 2005:1) dan Thomas (dalam Ahmadi, 1991:162) sikap pada dasarnya mengandung tiga komponen, yaitu the cognitive, affective, and conative. Komponen kognitif dalam suatu sikap akan berhubungan dengan pikiran atau keyakinan mengenai suatu objek. Hal ini ditegaskan oleh Gardner (dalam Hohental, 2005:1) bahwa the cognitive component refer to an individual's belief structure. Oleh karena itu, sikap terhadap suatu objek tertentu dapat mencakup pemahaman mengenai unsur-unsur objek tertentu pula. Pemahaman mengenai komputer misalnya dapat menyangkut pengetahuan komponenkomponen komputer, seperti kursor, monitor, printer, dan sebagainya. Kognisi yang paling kritis dan menyatu dalam sistem sikap merupakan keyakinan evaluatif yang melibatkan diberikannya kualitas disukai atau tidak disukai, diperlukan atau tidak diperlukan, baik atau buruk terhadap suatu objek. Komponen kognisi juga dapat mencakup keyakinan seseorang mengenai cara-cara yang sesuai dan tidak sesuai dalam menanggapi suatu objek, misalnya warga Negara Indonesia yang berideologi komunis di Indonesia harus dipenjara. Oleh karena itu, kognisi dan kecenderungan tingkah laku berhubungan sangat erat.

Komponen afeksi dalam suatu sikap berkaitan dengan emosi terhadap suatu objek. Dalam hal ini, Gardner (dalam Hohenthal, 2005:1) dan Rochmah, 
dkk, 1996:8) secara singkat menegaskan bahwa the affective to emotional reactions. Reaksi terhadap objek tersebut dirasakan sebagai hal yang menyenangkan atau tidak menyenangkan, disukai atau tidak disukai. Beban emosi inilah yang memberikan watak tertentu terhadap sikap, yaitu watak yang mantap, tergerak, dan termotivasi. Jika ada seorang sastrawan, sastrawan tersebut merasa ramah terhadap sastrawan lain, menyukai hasil karya-karya sastranya, menyukai kiprahnya dalam dunia sastra, serta mengikuti perkembangan karyakarya sastranya.

Komponen konasi merupakan kecenderungan tindakan yang meliputi kesiapan perilaku yang berkaitan dengan sikap. Menurut Gardner (dalam Hohenthal, 2005:1), komponen konasi merupakan the tendency to behane in a certain way towards the attitude. Apabila seorang individu bersikap positif terhadap objek tertentu, individu tersebut akan cenderung membantu atau memujinya. Namun, apabila seorang individu bersikap negatif, individu tersebut akan cenderung mengganggu, menghukum, atau merusak terhadap objek tersebut. Jika seseorang tidak menyukai Amerika misalnya, orang tersebut mungkin berkecenderungan untuk menghindari, menolak berkawan, tidak mau membantu, atau bahkan memperlakukan orang Amerika sebagai musuhnya.

Pendapat tentang sikap yang agak berbeda dan sebagai pelengkap atau pembanding pendapat di atas dikemukakan oleh Thurstone (dalam Walgito,1991: 107-106-108) mengata-kan bahwa An attitude is the degree of positive or negative effect associated with same psychological object; yakni sikap sebagai suatu tingkatan kecenderungan yang bersifat positif atau negatif yang berhubungan dengan objek psikologi. Dengan demikian, sikap itu merupakan bentuk evaluasi atau reaksi perasaan. Sikap seseorang terhadap suatu objek adalah perasaan mendukung atau tidak memihak pada objek sikap.

Bagaimanakah pendapat tentang sikap dari ahliahli yang lain? Pendapat Thurstone tentang sikap tersebut di atas ternyata selaras dengan pendapat Anastasi (1976:543) yang mengatakan bahwa " $A n$ attitude is often defined as a tendency to react faforably towant a designated class of stimuli, such as a national or racial group, a custom, or a institution". Pendapat tentang sikap ini ditegaskan oleh Arkinson, Smith, Bem, dkk. (1987:569) yang mengatakan bahwa sikap merupakan penilaian terhadap objek, orang, situasi, dan mungkin aspekaspek lain termasuk ide abstrak, dan kebijaksanaan sosial yang meliputi rasa suka atau tidak suka dan reaksi menyenangkan atau tidak menyenangkan. Dalam hal ini, Suharyat menegaskan bahwa sikap adalah kecenderungan individu menanggapi secara positif atau negatif terhadap obyek sikap ditinjau dari dimensi kognisi, afeksi dan konasi (http://ejournalunisma.net/ojs/index.php/region/article/viewFile/22/ 20. Diakses 12 Oktober 2017).

Apabila dicermati dengan seksama, batasan tentang sikap di atas dapat dikatakan sebagai suatu kecenderungan bereaksi setelah dilakukan evaluasi terhadap objek sikap. Kecenderungan bereaksi ini dalam bentuk perasaan mendukung atau perasaan tidak mendukung terhadap suatu objek tertentu. Reaksi perasaan ini terjadi setelah seseorang mengadakan evaluasi terhadap rangsangan yang datang kepada dirinya. Berarti, konsep sikap dapat dikatakan berkonotasi konsistensi respons dalam hubungannya dengan stimulan. Respons ini dapat diklasifikasikan menjadi tiga macam, yaitu respons kognisi (segala pernyataan yang diyakini), respons afeksi (memperlihatkan simpati), dan respons konasi (tindakan mengenai tingkah laku). Oleh karena itu, sikap tidak dapat diamati secara langsung, tetapi 
harus ditentukan melalui analisis tingkah laku yang tampak, baik analisis atas dasar pengamatan verbal maupun nonverbal.

Mengingat penelitian kualitatif bersifat alami yang berarti peneliti dapat menjadi instrumen, maka pada awal penganalisisan perlu dilakukan reduksi data, yaitu mengumpulkan, menggolong-golongkan, dan mengorganisasi data sehingga dapat dilakukan interpretasi data. Berikutnya, analisis data kualitatif merupakan bagian dari penyajian data kualitatif, yakni penyusunan sejumlah informasi sehingga dapat menarik suatu kesimpulan. Dalam tulisan ini disajikan secara naratif. Setelah dilakukan reduksi dan analisis, maka dapat baru dapat menarik kesimpulan, yakni apakah dapat dikategorikan positif atau negatif.

Sikap bahasa adalah pendirian atau keyakinan seseorang terhadap suatu bahasa dan pendirian seseorang terhadap bahasa ini bersifat relatif. Akan tetapi, pendirian ini berkecenderungan terekspresikan ke dalam perbuatan nyata dalam berbahasa. Hal yang seharusnya dipahami adalah pendirian atau keyakinan ini bersifat relatif. Hal ini disebabkan pendirian atau keyakinan tentang kebahasaan itu merupakan peristiwa kejiwaan sehingga bentuk manifestasinya dapat berupa suka atau tidak suka, peduli atau tidak peduli, acuh atau tak acuh terhadap bahasa Indonesia. Sikap bahasa yang dapat berupa pendapat, gagasan, keyakinan, dan prasangka yang dimiliki pembicara selayaknya lebih konsisten terhadap penggunaan bahasa yang sesuai dengan norma-norma kebahasaan, yakni bahasa Indonesia. Dengan demikian, kekonsistenan antara sikap bahasa dan implementasi berbahasa terjadi dalam berbahasa.

\section{Konsistensi}

Dalam Kamus Besar Bahasa Indonesia (1999:457), konsistensi berarti ketepatan dan kemantapan dalam bertindak; ketaatasasan, sedangkan berbahasa adalah memakai atau menggunakan bahasa. Menggunakan bahasa merupakan suatu proses pengungkapan pikiran, perasaan, gagasan, keinginan, dan fakta dalam konteks komunikasi. Berarti, konsistensi bahasa dapat dimaknai berperilaku tetap berpegang teguh pada kaidah-kaidah bahasa pada saat berkomunikasi, baik secara lisan maupun tulis. Konsistensi dapat berarti suatu tindakan yang selalu berpegang teguh pada prinsip yang telah ditetapkan dalam diri seseorang yang diimplentasikan dalam kehidupan. Idealnya, sikap itu termanifestasikan ke dalam perbuatan nyata sehingga sikap yang terdiri atas kognisi, afeksi, dan konasi terjadi ketaatasasan hubungan yang selaras.

Cerminan perilaku konsisten-tidaknya seseorang berbahasa antara lain dapat terlihat pada saat seseorang berpikir, bertutur atau berbicara, yakni tindakan atau perbuatan nyata dalam menggunakan bahasa; apakah teguh dalam berprinsip dan apakah juga korektif dalam berhasa. Mengingat, seseorang dalam berpikir dan berbicara akan memperhatikan dan memformulasikan kaidah-kaidah alat berpikir, yakni bahasa. Seseorang salah dalam menggunakan alat berpikir maka dapat berakibat salah pula dalam berpikir seseorang. Langacker (dalam Pateda, 1988: 31) mengatakan bahwa pikiran dikondisi oleh kategori linguistik dan pengalaman yang akan dikodekan dalam wujud konsep kata yang telah tersedia. Dengan kata lain, bahasa dapat membantu pemikiran manusia supaya dapat berpikir lebih sistematis.

Bagaimanakah keterkaitan antara sikap dengan konsistensi dalam perilaku berbahasa Indonesia? Dalam hal ini, Suharyat (2009) menjelaskan bahwa sikap dan perilaku ada kesamaan. Oleh karena itu, psikolog sosial, seperti 
Morgan dan King, Howard dan Kendler, serta Krech dkk., mengatakan bahwa antara sikap dan perilaku adalah konsisten. Apakah selalu bahwa sikap konsisten dengan perilaku? Seharusnya, sikap adalah konsisten dengan perilaku, akan tetapi karena banyaknya faktor yang mempengaruhi perilaku, maka dapat juga sikap tidak konsisten dengan perilaku. Dalam keadaan yang demikian terjadi adanya desonansi nilai (http://ejournalunisma.net/ojs/index.php/region/article/viewFile/22/ 20).

\section{Ragam Bahasa Keilmuan}

Bahasa Indonesia sebagai sarana komunikasi keilmuan menggunakan ragam ilmiah. Ragam bahasa keilmuan dan sering disebut ragam ilmiah ini harus mengikuti kaidah-kaidah tata bahasa Indonesia, tata istilah, dan pedoman ejaan bahasa Indonesia yang disempurnakan. Ragam kelimuan yang termasuk di dalamnya bidang keteknikan sangat memerlukan kecermatan, keringkasan, dan kejelasan. Mengapa berbahasa Indonesia bidang teknik khususnya ilmu pengetahuan dan teknologi pada umumnya ini harus cermat, ringkas, dan jelas? Apabila memeperhatikan gagasan yang diiformasikan, bahasa bidang teknik ini menuntut tingkat kepastian yang tinggi. Dengan tuntutan tersebut, bahasa Indonesia ragam ilmu pengetahuan dan teknologi harus benar-benar dapat memberikan informasi dengan cacat sekecil-kecilnya sehingga ragam bahasa tersebut dapat digunakan sebagai penyebarluasan konsep-konsep ilmu pengetahuan dan teknologi (Hadiwidjoyo, 1983:101; Alwi, 2000:95; Poedjosoedarmo, 2000:71). Dengan cacat sekecil-kecilnya, gagasan yang diinformasikan diharapkan dapat dipahami pembaca dengan tepat dan jelas. Oleh karena itu, pemakai bahasa Indonesia dalam bidang keteknikan ini harus memperhatikan kaidah pemakaian berbagai aspek kebahasaan dengan sangat taat asas, seperti kaidah ejaan, kata, istilah, kaimat, dan paragraf.

Apabila memperhatikan beberapa pendapat di atas, kemampuan berbahasa Indonesia sebagai sarana komunikasi ilmu pengetahuan dan teknologi seharusnya tidak diragukan. Bukan kemampuan bahasa Indonesia yang diragukan, justru kemampuan pemakai bahasa Indonesia yang diragukan. Bahasa Indonesia bukan tidak mampu sebagai alat komunikasi ilmu pengetahuan dan teknologi, tetapi pemakai bahasa Indonesia yang tidak mampu menggunakannya (Moeliono, 1991:34; Putra dan Thohari, 2000:274). Benarkah pendapat sebagian masyarakat yang mengatakan bahwa pemakai bahasa Indonesia, khususnya yang berkecimpung dalam bidang ilmu pengetahuan dan teknologi kurang mampu berbahasa Indonesia secara tepat dan benar? Dalam hal ini, Putro dan Thohari (2000:274) menegaskan bahwa upaya mewujudkan bahasa Indonesia sebagai bahasa pembangunan yang berwawasan iptek masih jauh dari harapan sehingga penggunaan bahasa keilmuan belum mantap. Pendapat pertama yang mengatakan bahwa bahasa Indonesia diragukan kemampuannya untuk mengkomunikasikan ilmu pengetahuan dan teknologi perlu dipertanyakan. Dalam hal ini, Pusat Pembinaan dan Pengembangan Bahasa (1992:674) menyatakan bahwa bahasa Indonesia telah mampu menjalankan fungsinya sebagai penyebar ilmu dengan baik. Hal ini terbukti dengan semakin banyaknya ilmu pengetahuan dan teknologi tingkat tinggi yang ditulis dalam bahasa Indonesia atau diterjemahkan dalam bahasa Indonesia.

Dalam aktivitas berpikir, bahasa Indonesia dapat difungsikan sarana dan manifestasi berpikir ilmiah serta digunakan untuk mengkomunikasikan hal-hal ilmiah dengan berbagai pihak yang berkepentingan. Mengenai bentuknya, sarana yang 
berupa bahasa dapat berbentuk lisan dan tulisan. Mengingat, tujuan berkomunikasi adalah mengungkapkan pikiran, keinginan, dan kehendak kepada pihak kedua sebagai komunikan. Dalam berbahasa, pengguna bahasa dapat menyesuaikan diri dengan norma-norma masyarakat. Peristiwa berbahasa itu menunjukkan bahwa berbahasa diperlukan suatu proses berpikir yang tersetruktur dengan baik. Dengan demikian, bahasa merupakan sarana perwujudan pikiran pengguna bahasa karena segala sesuatu yang dibicarakan adalah sesuatu yang dipikirkan.

Bahasa sebagai sarana komunikasi bersifat sistematis. Wujud nyata bahasa ini adalah suara atau simbol konvensional. Berarti, bahasa merupakan sistem yang difungsikan untuk mengutarakan dan melaporkan segala sesuatu yang terjadi pada sistem saraf. Sistem ini berkoordinasi yang bertugas menyampaikan rangsangan dari reseptor untuk dideteksi dan direspon oleh tubuh. Sistem saraf ini memungkinkan makhluk hidup tanggap dengan cepat terhadap perubahan-perubahan yang terjadi di lingkungan luar maupun dalam. Sebuah sistem katakata yang digunakan untuk menamai sesuatu dalam disiplin tertentu. Berpikir merupakan ciri utama bagi manusia, untuk membedakan antara manusia dengan makhluk lain. Dengan dasar berpikir, manusia dapat mengubah keadaan alam sejauh akal dapat memikirkannya. Berpikir merupakan proses bekerjanya akal, manusia dapat berpikir karena manusia berakal. Akal merupakan salah satu unsur kejiwaan manusia untuk mencapai kebenaran di samping rasa dan kehendak untuk mencapai kebaikan.

Apabila dicermati, bahasa tidak hanya sebagai sarana mengungkapkan buah pikiran dan perasaan, tetapi bahasa sebagai sistem juga merupakan pencermat gagasan dan pengatur aktivitas seseorang, penganalisis terhadap kesan dan penyintesis terhadap objek yang diterimanya. Dalam hal ini, Whorf (dalam Berry, dkk. 1999:205) berpendapat bahwa system bahasa merupakan penajam gagasan yang terdapat pada bahasa itu sendiri dan pemandu aktivitas mental invidu. Hal ini menunjukkan bahwa bahasa dengan pikiran berhubungan erat karena tidak mungkin berpikir tanpa bahasa. Pemakaian bahasa yang kacau mengindikasikan terjadinya pikiran yang kacau pula. Hal ini dapat dipertegas oleh pendapat de Saussure (dalam Pateda, 1988:39) yang mengatakan bahwa bahasa bukanlah kekacauan, tetapi bersistem sehingga pemakai bahasa tidak akan saling memahami jika bahasa yang digunakan tidak bersistem. Oleh karena itu, Ryle (dalam Mahmud, 2004:1) seorang ahli filsafat menegaskan bahwa berpikir Vygotsky dan Sapir, berpendapat bahwa sistem bahasa dengan rumusannya atau perbendaharaan katanya, membentuk pikiran atau diperlukan untuk berpikir. Pada intinya, kemampuan berpikir bergantung pada kemampuan berbahasa dan akan menentukan dalam berpikir.

Bahasa Indonesia sebagai pengungkap gagasan keilmuan pasti tidak terhindar dari sentuhan dan pengaruh masyarakat yang memahaminya. Pengaruh ini dapat berupa perubahan nilai dan struktur kebahasaan. Di sisi lain, sikap pemakai bahasa Indonesia juga akan mengalami perubahanperubahan. Adanya hubungan timbal balik antara bahasa sebagai alat pengungkap gagasan dan fenomena sosial dapat menambah kekayaan ketatabahasaan bahasa Indonesia. Di samping itu, persentuhan dapat menimbulkan pula keanekaragaman. Oleh sebab itu, pengembangan dan pembinaan bahasa Indonesia harus dilakukan secara konsisten dan kontinu agar tidak terjadi ragam-ragam yang menyimpang terlalu jauh dari hakikat bahasa Indonesia. 
Sehubungan dengan perubahan sikap pemakai bahasa Indonesia seharusnya dipahami sebagai suatu peristiwa yang wajar dan positif. Mengingat, perubahan sikap tersebut menandakan bahwa pemakai bahasa Indonesia masih setia memakai bahasa Indonesia. Namun, pemakaian bahasa ini harus dikontrol dan dikendalikan supaya terjadi perubahan pemakaian bahasa Indonesia yang positif, yakni tetap mengidahkan kebaikan dan kebenaran berbahasa Indonesia sehingga tujuan penyampaian gagasan dalam komunikasi berlangsung dengan lancar. Dalam pengontrolan dan pengendalian berbahasa Indonesia ini, peran pembinaan bahasa Indonesia dari berbagai pihak, seperti Pusat Pembinaan dan Pengembangan Bahasa dan lembagalembaga pendidikan mulai dari tingkat dasar hingga pendidikan tinggi, sangat penting kontribusinya dalam mengawal perkembangan bahasa Indonesia. Selain itu, kegiatan penelitian, khususnya penelitian tentang sikap bahasa menjadi salah satu bagian yang strategis untuk mengetahui dan memahami kondisi kebahasaan. Dengan adanya pembinaan dan pengembangan secara serius dan berkesinambungan diharapkan arah pencapaian bahasa Indonesia yang baik dan benar di negeri ini dapat terwujud.

Kajian Konsistensi dan Sikap dalam Berbahasa

\section{Indonesia}

Bagaimanakah hubungan sikap dengan konsistensi dalam berbahasa? Dalam hal ini, Sugar menegaskan bahwa perilaku itu ditentukan oleh empat faktor utama, yakni sikap, norma sosial, kebiasaan, dan akibat yang mungkin terjadi (dalam Chaer dan Leonie, 2007). Dari keempat faktor itu dikatakan bahwa kebiasaan adalah faktor yang paling kuat, sedangkan sikap merupakan faktor yang paling lemah. Jadi, sikap bukan satu-satunya faktor yang menentukan perilaku, yang paling menentukan perilaku adalah kebiasaan (diakses, 10 Oktober 2017) http://guru-idaman.blogspot.co.id/2009/06/sikapdan-perilaku-berbahasa-indonesia.html

Kosistensi kebahasaan dapat berarti ketetapan, kamantapan (dalam bertindak) serta ketaatasasan dalam bertingkah laku sesuai dengan kaidah bahasa Indonesia. Bagaimanakah konsistensi mahasiswa sebagai pemakai bahasa keilmuan dalam bahasa Indonesia? Kejadian-kejadian di masyarakat ternyata kognisi dengan konasinya sering tidak selaras. Hal ini dapat dilihat pada tulisan berikut. Dari sejumlah responden diambil dua kasus. Menurut intuisi atau pertimbangan penulis terhadap responden, seperti telah dikemukakan Nasution di atas bahwa sampel penelitian kualitatif cenderung sedikit, hal ini dilakukan karena tanggapan responden-responden memiliki karakter pengetahuan dan konasi relatif sama.

Seperti yang telah disampaikan di atas, prosedur tahap ketiga yang dilakukan dalam tulisan ini adalah penulis menyiapkan pertanyaan kemudian ditanyakan kepada responden tentang bagaimanakah strategi pemberdayaan bahasa Indonesia. Tanggapan responden tersebut seperti berikut:

Responden ke-1.

strategi yang dapat kita lakukan . adalah dengan memberitahuakan atau saling mengingat.menggunakan bahasa Indonesia.kita sebagai warga Indonesia juga harus menjunjung tinggi bahasa persatuan kita yaitu bangsa Indonesia. Pada jaman globalisasi seperti sekarang memang bahasa Indonesia mulai perlahan-lahan memudar.kita boleh meniru gaya makanannya dan lain-lain.tapi tidak,kalau kita meniru bahasa lain.

Responden ke-2.

Dengan menanamkan sejak dini pengetahuan pengetahuan tentang bahasa Indonesia dan harus sangat di tekankan tidak hanya sekedar memberi pelajaran bahasa Indonesia tapi juga menjelaskan bagaimana pentingnya berbahasa Indonesia. salah satu strategi juga bisa juga dengan sekolah-sekolah.

Pada kalimat yang lain ditulis sebagai berikut:

Salah satu strategi bisa dengan aturan pada telepon genggam kita, aturan yang dimaksud adalah 
aturan berbahasanya dengan demikian paling tidak kita peduli memberdayakan bahasa Indonesia itu sendiri, kita juga perlu melatih diri kita berbahasa Indonesia yang baik dan benar sesuai ejaan yang disempurnakan, bukan berarti berbahasa Inggris tidak penting, namun dengan demikian berbahasa Indonesia selalu penting daripada itu.

Dari dua tulisan responden pertama dan kedua tersebut di atas, jika diperhatikan dari segi intensitas sikap kognisi dan afeksinya terhadap bahasa Indonesia, responden menunjukkan sikap positif, yakni semangat kognisi (pikiran) dan afeksi (perasaan) bahkan keyakinanannya terhadap bahasa Indonesia sangat baik. Namun, bagaimanakah penulisan ejaan, kata, dan tata kalimat tersebut di atas jika diperhatikan segi perwujudan konasinya? Tulisan tersebut terjadi banyak kesalahan ketatabahasaan, baik kesalahan penulisan ejaan, kata, dan tata kalimat.

Jawaban atas pertanyaan kepada responden tersebut banyak ditemukan kesalahan di berbagai kaidah bahasa Indonesia, misalnya penulisan kata, pilihan kata, dan penyusunan tata kalimat. Tulisan responden pertama banyak sekali kesalahan ketatabahasaannya, baik penulisan ejaan, tata kata, dan tata kalimat. Dalam hal ini, tulisan responden ke2 saja yang akan dibahas dalam tulisan ini, yakni sebagai berikut:

\section{a. Penulisan Kata Depan " $d i$ "}

Responden tidak mengtahui ada dua macam, yaitu "di" sebagai kata depan dan " $d i$ " sebagai awalan. Data dari responden misalnya di tekankan. Seharusnya, kata tersebut ditulis sebagai awalan untuk sebuah kata kerja pasif dan harus ditulis serangkai, yaitu ditekankan. Jadi, kata depan "di" pada data itu harus ditulis serangkai menjadi ... "sangat di tekankan tidak hanya" ... karena kata "tekan" merupakan kata kerja. Jika kata itu digabungkan dengan kata depan "di" maka kata “tekan” itu menjadi kata kerja pasif.

\section{b. Penggunaan Kata Penghubung "tetapi" dan “namun"}

Kata penghubung "tetapi” merupakan kata penghubung intrakalimat. Kata penghubung "akan tetapi" merupakan kata penghubung antarkalimat dan kata "namun”. Kata "namun” merupakan kata penghubung antarkalimat. Kata "namun" tidak tepat jika digunakan sebagai penghung intrakalimat. Dari data ditulis "tapi", bukan "tetapi". Kata "tapi" merupakan bentuk kata tidak baku. Kata "tapi" tidak tepat jika digunakan dalam tulisan formal atau tulisan ilmiah. Pada bagian data berikutnya ditemukan tulisan ... berbahasa Inggris tidak penting, namun dengan demikian...Jadi, kata "namun" diganti “tetapi” sehingga kalimatnya menjadi ... berbahasa Inggris tidak penting, tetapi dengan ....

c. Subjek, Predikat, Objek, dan Keterangan

Penulis sering kurang memperhatikan dan mengoreksi apakah kalimat-kalimat yang disampaikan itu memenuhi struktur kalimat. Sebenarnya, kalimat-kalimat yang disusun cukup mudah dipahami informasinya, tetapi setelah diperiksa, kalimat itu tidak memenuhi struktur inti kalimat. Dengan demikian, kalimat yang tidak memenuhi struktur inti suatu kalimat berakibat kerancuan informasi. Hal ini dapat dilihat pada data berikut:

(1). Dengan menanamkan sejak dini pengetahuan-pengetahuan tentang bahasa Indonesia dan harus sangat di tekankan tidak hanya sekedar memberi pelajaran bahasa Indonesia tapi juga menjelaskan bagaimana pentingnya berbahasa Indonesia. (2) Salah satu strategi juga bisa juga dengan sekolah-sekolah.

Kerancuan kalimat (1) di atas terjadi karena antara lain disebabkan oleh susunan kalimat yang tidak sesuai dengan pola kalimat bahasa Indonesia 
sehingga penyampaian pikiran atau gagasan yang sulit dipahami dengan baik. Demikian juga kalimat (2), terjadi ketidakjelasan informasi sehingga sulit untuk dipahami dengan baik.

Berdasarkan analisis aspek-aspek kebahasaan seperti di atas, terbukti bahwa konasi berbahasa Indonesia responden kurang relevan dengan aspek kognisi dan afeksinya. Dari hasil wawancara diperoleh informasi bahwa belajar bahasa Indonesia selama ini bertujuan untuk memperoleh nilai yang baik, bukan paham dan terampil berbahasa Indonesia. Di samping itu, tujuan belajar responden selama ini lebih pada pengayaan kognisi daripada konasi sehingga berakibat pada rendahnya pemahaman dan keterampilan berbahasa Indonesia.

\section{Simpulan}

Berdasarkan hasil kajian di atas menunjukkan bahwa antara sikap dan tindakan berbahasa Indonesia ragam keilmuan sering ditemui penggunaan bahasa yang tidak sesuai dengan standar ketatabahasaan berbahasa Indonesia.

Kekurangkonsistenan atau kekurang-sesuaian antara sikap kognisi dan afeksi dengan konasi sebagai perwujudannya ini meliputi penulisan ejaan, kata, dan tata kalimat. Idealnya, sikap berbahasa Indonesia yang dimiliki para mahasiswa sebagai calon pemimpin bangsa menunjukkan sikap yang positif. Namun, pendapat, keyakinan, atau kecenderungan berbahasa mahasiswa bidang keteknikan ini masih kurang relevan dengan sikap konasinya sebagai perwujudan kognisi dan afeksinya dalam berbahasa Indonesia. Dalam hal ini, kognisi dan afeksinya kurang menjadi dasar pertimbangan dalam berbahasa Indonesia bidang keilmuan.

Pembinaan dan pengembangan bahasa Indonesia harus ditingkatkan, baik kualitas maupun kuantitasnya. Pembinaan ini harus melibatkan berbagai pihak, antara lain pemerintah dengan kebijakan-kebijakan politik kebahasaan, lembagalembaga pendidikan dari tingkat dasar sampai dengan tingkat tinggi, dan masyarakat beserta tokohtokohnya. Peran pemerintah sangat strategis karena pemerintah memiliki kewenangan yang besar terhadap bahasa Indonesia. Mengingat, bahasa Indonesia adalah resmi negara dan sekaligus bahasa persatuan. Lembaga pendidikan melalui tenagatenaga pendidkan dapat lebih dimaksimalkan usahausaha kependidikannya. Selain itu, tidak kalah strategisnya tokoh-tokoh masyarakat sebagai panutan masyarakat juga dilibatkan dalam usaha pembinaan dan pemgembangan bahasa Indonesia. Dengan peran dari berbagai pihak diharapkan bahasa Indonesia memiliki warwah di negeri sendiri dan bahkan masyarakat dunia.

\section{Daftar Pustaka}

Ahmadi, H. Abu. (1991). Psikologi Sosial. Jakarta: Melton Putra.

Alwi, Hasan. (2000). Tata Bahasa Baku Bahasa Indonesia. Jakarta: Balai Pustaka.

Anastasi, Anne.(1976). Psycological Testing. New York: Maxmillan Publissing Co. In.

Atkinson, Rita L. Atkinson Richard C. Edward E. Cs. (1997). Pengantar Psikologi. Jakarta. Internusa.

Berry, dkk. (1999). Psikologi Lintas Budaya: Riset dan Aplikasi. Jakarta: Gramedia Pustaka Utama.

Departemen Pendidikan dan Kebudayaan. (1989). Kamus Besar Bahasa Indonesia. Jakarta: Balai Pustaka.

Departemen Pendidikan dan Kebudayaan. (1992). Kongres Bahasa Indonesia IV. Jakarta: Pusat Pembinaan dan Pengembangan Bahasa.

Hadiwidjojo, MM. Purbo. (1983). Menyusun Laporan Teknik. Bandung ITB.

Hohenthal, Anika. Measurement Techniques - What is Language Attitude. Departement of English. University of Turku. Finland.

Mahmud, Fikri. (2004). Antara Bahasa, Pikiran dan Tindakan. Kuala Lumpur: http://fikrimahmud.tripod.com/artikelid 11. Html.diakses 10 Oktober 2017. 
Marsudi, Siti Zahrok, dan U. A. (2013). KESADARAN PEMAKAI BAHASA INDONESIA DI ERA TEKNOLOGI. Jurnal Sosial Humaniora (JSH), 6(24), 156-170. https://doi.org/http://dx.doi.org/10.12962/j2443 3527.v6i2.604

Marsudi, S. Z. (2015). KESETIAAN BERBAHASA INDONESIA DIPERTANYAKAN DI ERA GLOBALISASI. Jurnal Sosial Humaniora (JSH), 8(1), 95-105. https://doi.org/http://dx.doi.org/10.12962/j244 33527.v8i1.1245

Moeliono, Anton M. (1991). Santun Bahasa. Jakarta: Gramedia Putra Utama.

Pateda, Mansoer. (1988). Aspek-Aspek Psikolinguistik. Ende-Flores: Nusa Indah.

Rochmah, Siti, dkk. (1978). Sikap Sosial. Jakarta: Pusat Pembinaan dan Pengembangan Bahasa.

Sugiono. (2009). Metode Penelitian Pendekatan Kuantitatif, Kualitatif dan $R \& D$. Bandung: Alfa Beta.

Suharyat, Yayat. (2009). Hubungan antara Sikap, Minat, dan Perilaku Manusia. http://ejournalunisma.net/ojs/index.php/region/article/viewFi le/22/20.diakses 10 Oktober 2017.

Sunarto. (2001). Metodologi Penelitian Ilmu-Ilmu Sosial \& Pendidikan. Surabaya: Unesa University Press.

Walgito, Bimo. (1991). Psikologi Sosial: Suatu Pengantar. Yogyakarta: Andi Offset.

www.ilmubahasa.net, Gudangnya Materi Ilmu Bahasa, Media Karya Sastra dan Informasi. http://www.ilmubahasa.net/2016/12/tekniksampling-penelitian kualitatif.html. diak-ses 10 Oktober 2017 